\title{
Pesticide-Handling Practices in Agriculture in El Salvador: An Example from 42 Patient Farmers with Chronic Kidney Disease in the Bajo Lempa Region
}

\author{
Roberto Mejía ${ }^{1}$, Edgar Quinteros' ${ }^{1}$, Alejandro López ${ }^{1}$, Alexandre Ribó ${ }^{1}$, \\ Humberto Cedillos ${ }^{2}$, Carlos M. Orantes ${ }^{1}$, Eliette Valladares ${ }^{1}$, Dina L. López ${ }^{3}$ \\ ${ }^{1}$ National Institute of Health, Ministry of Health of El Salvador, San Salvador, El Salvador \\ ${ }^{2}$ University of El Salvador, San Salvador, El Salvador \\ ${ }^{3}$ Department of Geological Sciences, Ohio University, Athens, OH, USA \\ Email: robertomejia1685@gmail.com
}

Received 17 June 2014; revised 20 July 2014; accepted 10 August 2014

Copyright (C) 2014 by authors and Scientific Research Publishing Inc.

This work is licensed under the Creative Commons Attribution International License (CC BY). http://creativecommons.org/licenses/by/4.0/

(c) (i) Open Access

\section{Abstract}

Introduction: The occupational toxic risks from agricultural activities in El Salvador affect human and environmental health. The objective of this paper is to describe the management of pesticide by farmers confirmed with a chronic kidney disease of uncertain etiology (CKDu) not associated to diabetes mellitus or hypertension. Methods: The study involved 42 male patients older than 18 years old with confirmed CKDu that have participated in different stages of pesticides management. This is a cross-sectional study; it was conducted from January to June 2011, in three communities of Bajo Lempa region, El Salvador. An interview was especially designed to investigate which pesticides were used and the farmer practices at different stages of pesticide use. Statistical descriptive analysis was carried out for the several studied variables. Results: All interviewed people had a direct relationship with agricultural activities. The majority of patients had poor education, $19 \%$ were illiterate and $55 \%$ only have primary education. Most farmers with CKDu had been exposed more than 10 years to hazardous pesticides. The most used pesticide was Hedonal/2, $4 \mathrm{D}(100 \%) .95 \%$ interviewed patients mixed different pesticides and $63 \%$ dumped empty pesticide containers in the fields. Interviewees did not use appropriate personal protective equipment $(100 \%)$. Conclusions: There is high use of hazardous pesticides by patients and some of these are banned and some are legal in El Salvador, but prohibited by other countries. Interviewed CKDu patients had high exposure to toxic pesticides due to the misuse in almost all stages. There is inadequate legislation and a poor law enforcement to prevent the misuse of pesticides in El Salvador. 


\section{Keywords}

\section{Bajo Lempa, Pesticides, El Salvador, CKDu, Chronic Kidney Disease of Uncertain Etiology}

\section{Introduction}

The global use of pesticides generates substantial negative health impacts in all parts of the world, although the exact toll is difficult to determine due to both the variety of chemicals, and the types of exposure [1]. The World Health Organization (WHO) has established hazard category for pesticides: Ia Extremely Hazardous, Ib Highly Hazardous, II Moderately Hazardous, III Slightly hazardous, and U Unlikely hazardous (WHO 2009) [2]. Toxicity effects can be divided broadly into two categories: acute effects, which appear immediately or shortly after exposure; and chronic effects, which may manifest many years later and their etiology origins are often difficult to trace [3]. A higher proportion of pesticide poisonings and deaths occur in developing countries where there are inadequate occupational safety standards, lack of use of protective clothing and low number or absence of hygienic and clean facilities, insufficient enforcement, poor labeling of pesticides, illiteracy, and insufficient knowledge of pesticide hazards [4]. Pesticide management by farmers can be described and classified in different stages: purchasing and selection, transportation, storing, formulation, application and disposal of residues and wastes. Several studies have identified various hazards derived from pesticide mismanagement at these stages [5] [6], especially in developing countries [7] [8].

Central America is a region that imports more tons of pesticides in the world [9]. In this region it is estimated that around 400,000 people may suffer a symptomatic episode of pesticide poisoning each year [10]. The Ministry of Health of El Salvador reported 9981 acute poisonings between 2007 and 2012 [11]. In 2005-2010, El Salvador imported almost 16 million $\mathrm{kg}$ of pesticides, with an increase of $171 \%$ over the period [12]. According to the Ministry of Agriculture and Livestock of El Salvador, in 2012, 109 different types of insecticides and 68 different types of herbicides were sold [13]. Paraquat is the most sold pesticide in El Salvador [14] and it has been banned since 2009 by European Union [15]. El Salvador signed and accepted the Rotterdam Convention [16]. This convention is a multilateral treaty to promote shared responsibilities in relation to the import of hazardous chemicals. However, as it will be discussed later on, many pesticides included in the Rotterdam Convention are still in use in El Salvador.

A Chronic Kidney Disease of uncertain etiology (CKDu) not associated to diabetes mellitus or hypertension and recognized as Tubulointerstitial Chronic Kidney Disease of Central America by the Central American Integration System in the declaration of San Salvador [17] affects agricultural communities of El Salvador in endemic and epidemic proportions, particularly male farmers and also affects women and adolescents with lower frequency [18]-[20]. Studies carried out within NEFROLEMPA project observed a high prevalence of CKDu in the population of Bajo Lempa [21]. According recent publications, CKDu could be related to working conditions, such as intense use of pesticides, high ambient temperatures and intense physical activity with suboptimal hydration, among others [18]-[20].

The Bajo Lempa is a region located in the eastern coastal plain of El Salvador, in the south side of the departments of Usulután and San Vicente (Figure 1). This region expands along Lempa River delta plain, between the Salvadoran Pacific Coastline and the Littoral highway. The Lempa River is the longest in Central America and its basin extends throughout Salvadoran territory but also drains parts of Honduras and Guatemala. Most of the area of the Lempa River basin is agricultural land and this basin drains the waters from the most important populated areas of El Salvador and several industrial areas. The Bajo Lempa region is one of the most important agricultural areas of El Salvador; this area presents high fertility soils due to the nutrients brought by frequent floods [22] [23]. This region is characterized by high poverty rate [24]. The social vulnerability of the population is incremented because they have been affected by several disastrous floods during the last 20 years like the floods produced by Hurricane Mitch or the Storm Ida [25]. Moreover, the basic services of these communities are only partially provided, for example, the drinking water network was installed only ten years ago.

Bajo Lempa is a region with important environmental resources. This region has the largest area of brackish and saltwater forests in El Salvador; these wetlands are a Ramsar site and Biosphere Reserve by UNESCO. Other environmentally significant area is the Nancuchiname forest, one of the few surviving lowland tropical 


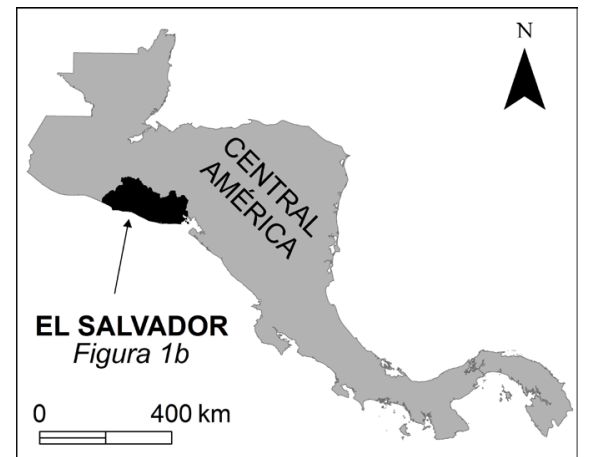

(a)

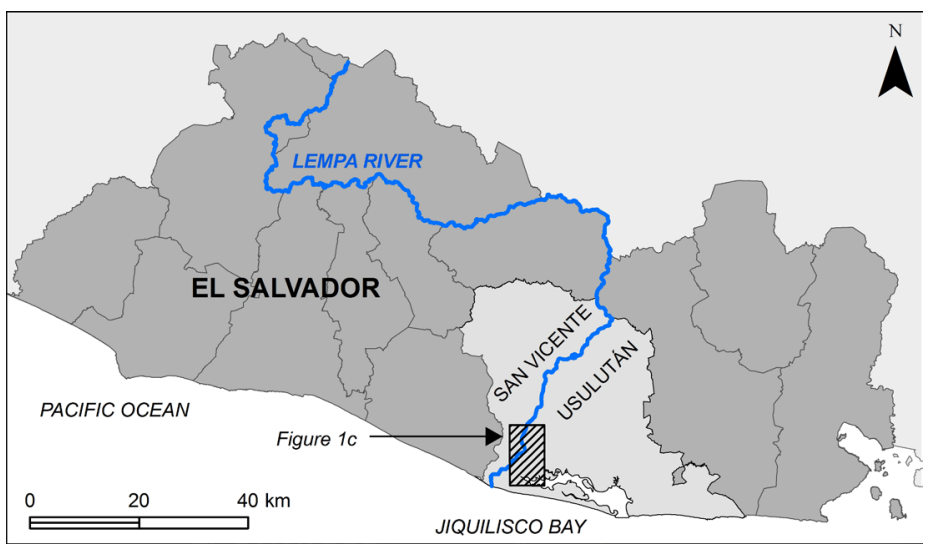

(b)

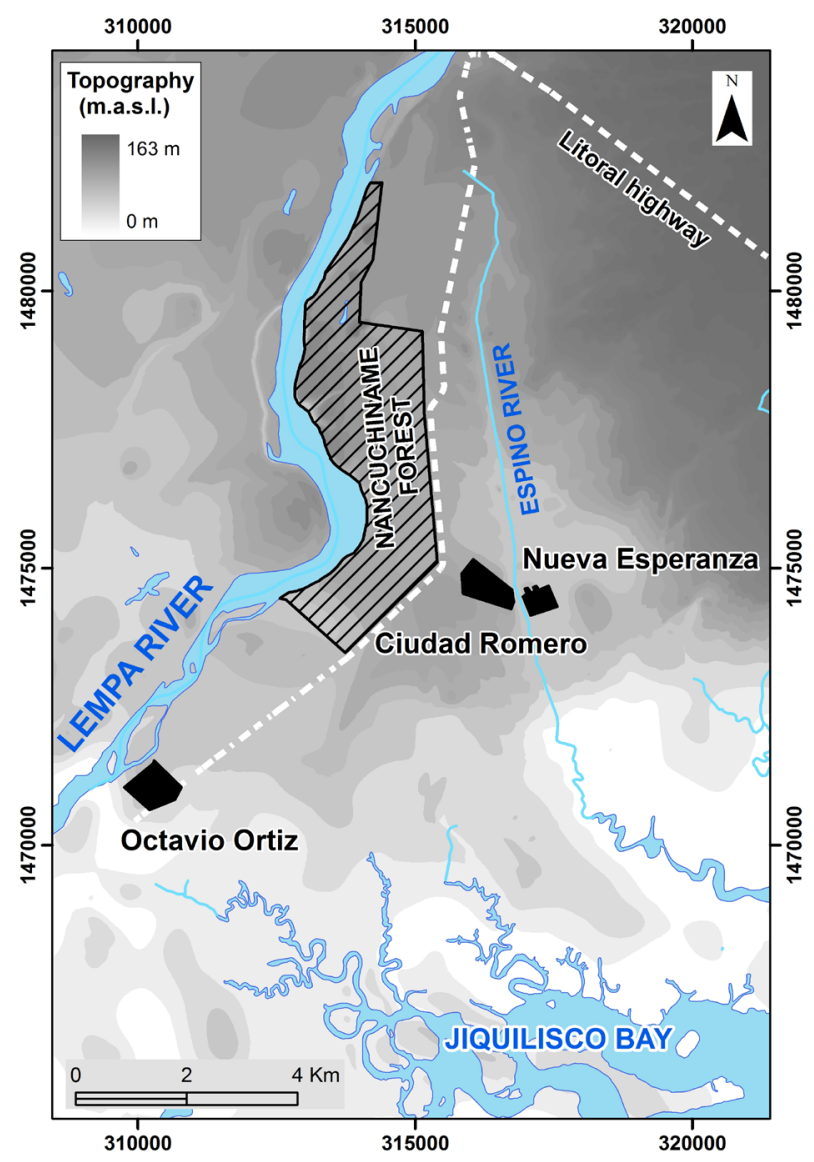

(c)

Figure 1. Location of El Salvador in Central America (a), map of El Salvador (b), location of the studied communities: Ciudad Romero, Nueva Esperanza and Octavio Ortiz (c).

forest in the country [26]. Since the last decade of XX century, the soil use of Bajo Lempa is mainly family farming, large-scale agriculture, diary production and marine shrimp cultivation. The family farming (corn, sorghum, vegetables, beans and other crops) is the main livelihood, as well as other activities as small family business [25]. The large scale agriculture is focused mainly on sugar cane and corn cropping managed by communal cooperative organizations. The present paper was developed within the framework of the NEFROLEMPA study. The purpose of this research is to describe the toxic risks in the work place which patients with CKDu have been exposed and studied. 


\section{Methods}

\subsection{Study Area and Population Selected}

This is a cross-sectional study, it was conducted from January to June 2011, in Nueva Esperanza, Ciudad Romero and Octavio Ortiz communities of Bajo Lempa region, which belongs to Jiquilisco municipality, department of Usulután, El Salvador. These three communities are characterized by important agricultural activity, mainly agriculture subsistence as corn, beans and orchards, and production of sugarcane in cooperatives. According NEFROLEMPA study [21] these communities present 320, 403 and 155 inhabitants respectively.

The study involved 42 male patients older than 18 years with confirmed CKDu, considering that they are farmers and they have participated in different stages of pesticides management: purchasing and selection, transportation, storing, formulation, application and disposal of residues and wastes. Women were not including in this study because they generally dedicate their time to housework. This population was taken from NEFROLEMPA Study 2009 that identified 54.7\% confirmed with CKDu (Overall = 76; Male = 51; Female $=25)[20]$.

\subsection{Survey Design}

The survey was based on the United States Environmental Protection Agency's questions related to safe pesticide use [27] and on surveys used in similar published studies [5] [28]. An interview of 45 minutes was conducted for each patient of the study. All participants considered in the research conducted within the NEFROLEMPA project, included the participants of this study gave their written informed consent after hearing the project objectives [21]. Some questions included in the survey were not relevant for the proposed objectives and are not contained in this paper. All questions were closed questions in a multiple choice format, in this way, respondents only had to choose the appropriate answer. Some questions demanded multiple answers. This study does not contain clinical studies or patient data.

The survey contained three sections. The first one was demographic section, which contained questions regarding time of residence in the community, age, marital status and education level. The second section of the survey consisted in questions related to pesticide practices. These questions include: number of years of pesticide use, what are the names of the most common pesticides purchased and if safe data sheets (SDS) were provided. The questions related to pesticides mobilization ask about how the products are transported from the shop to the storage place. In the section related to pesticides storage, the farmers were asked if they stored the pesticides outside or inside their homes, about storage conditions and if pesticides are stored in a restricted place out of reach of children and animals. Regarding the stages of formulation, the questions included the place where the pesticide were stored, who carried out this operations, and if they mixed different pesticides and their identification. Patients were interviewed about application and disposal of empty containers and pesticides solutions. Finally, interviewees were asked if they used Personal Protective Equipment (PPE), and about the composition of this equipment.

\subsection{Data Analysis}

The survey data were analyzed statistically using Microsoft Excel ${ }^{\mathrm{TM}}$ software (Version 2007). First of all it summarized responses overall populations (we calculated frequencies for the responses, percentage for categorical variables). Averages for age and education were calculated. Mean differences were declared significant at the $95 \%$ confidence level. After interviews, a checkup was performed to corroborate data provided by interviewees. This verification consisted in field visits and home visits to observe pesticides storage and checking the way they handled pesticides in stages of formulation, application and waste disposal.

\section{Results}

Interviewees were between 18 and 84 years old and around half answers (54\%) were obtained between 45 to 70 years old. The average age was 53 years old. According to educational level, $19 \%$ are illiterate and around half (55\%) only have primary education (elementary school), and could be classified as semi-illiterate with poor reading skills. In addition to practicing agriculture, all interviewees also practiced other subsistence activities such as shoemaking, masonry and trading.

Purchasing, buying and pesticide management was made by almost all the interviewees themselves (98\%); 
according field investigations, these pesticides were usually bought in a small shop close to the communities and in wholesale farmer stores in Jiquilisco and Usulután. Few interviewees did not receive SDS at the moment of buying (17\%).

Most common pesticides used were the following herbicides: Hedonal/2,4D (100\%), Paraquat/Gramoxone (97.6\%) and Glyphosate/Roundup (73.8\%). The most used pesticide families were: Phenoxyacetic Acid Group (100\%), Bipyridyl (97.6\%) and Organophosphate (81\%). Table 1 shows the list of used pesticides by the interviewed farmers, the observed proportion of their use, their chemical name, the chemical family which belong, the WHO classification of each pesticide by their hazard effects and some examples of adverse effects reported in the scientific literature.

Almost of all farmers transport pesticides themselves (98\%) and used the original container (98\%). Around half interviewed population transports them by truck or pick up (59\%), by bus (49\%), on foot (46\%) or some by bike (27\%). The means of transportation depend on the proximity of the shop, and the farmers storage place. The majority of the surveyed people (66\%) transported pesticides with other people, food and/or animals.

The majority of the patients stored pesticides in the living areas (74\%). Farmers keep pesticides in their original containers (94\%) and did not restrict the access to the storage areas (97\%). In a few cases, they stored pesticides inside their home in unsafe places such as kitchen and bedrooms (10\%) and the rest stored them outside their home, in shelves and cabinets located at the porch, latrines and trees, or directly on the floor of their garden/backyard. According to the field visits, these locations are accessible to children, livestock (hens and pigs) and pets. Most of the storing places are closer to the domestic well located in the garden/backyard.

Almost all interviewees carry out the preparation in the working areas (crop fields). Mixing different pesticides is a common practice in this region (95\%). Figure 2 represents several mixtures identified in this study according to the trade names. The main mixtures formulated are Hedonal - Paraquat/Gramoxone (43\%) followed by Hedonal - Ranger and Hedonal - Batalla (14\% respectively).

Almost all (95\%) have applied pesticides. From these farmers only $40 \%$ continued applying pesticides nowadays. The pesticides are applied using a backpack sprayer, composed by a deposit of 17 L capacity, a hand-operated pump, a pressure vessel, a hose and a spray lance with cut-off valve (100\%). Few farmers also apply them manually (5\%).

A good proportion of interviewees (50\%) normally apply the leftover solution over a non-cropped area close to their crops. Some farmers re-spray the treated crop until the spraying tank is empty (23\%) or they store the leftover solution for another application (20\%) and few farmers (15\%) release the solution directly to the floor in their working area or combine different release options. The majority of the interviewees (63\%) dump empty containers in the field. Some farmers (28\%) burn containers in open fires and few (10\%) bury them.

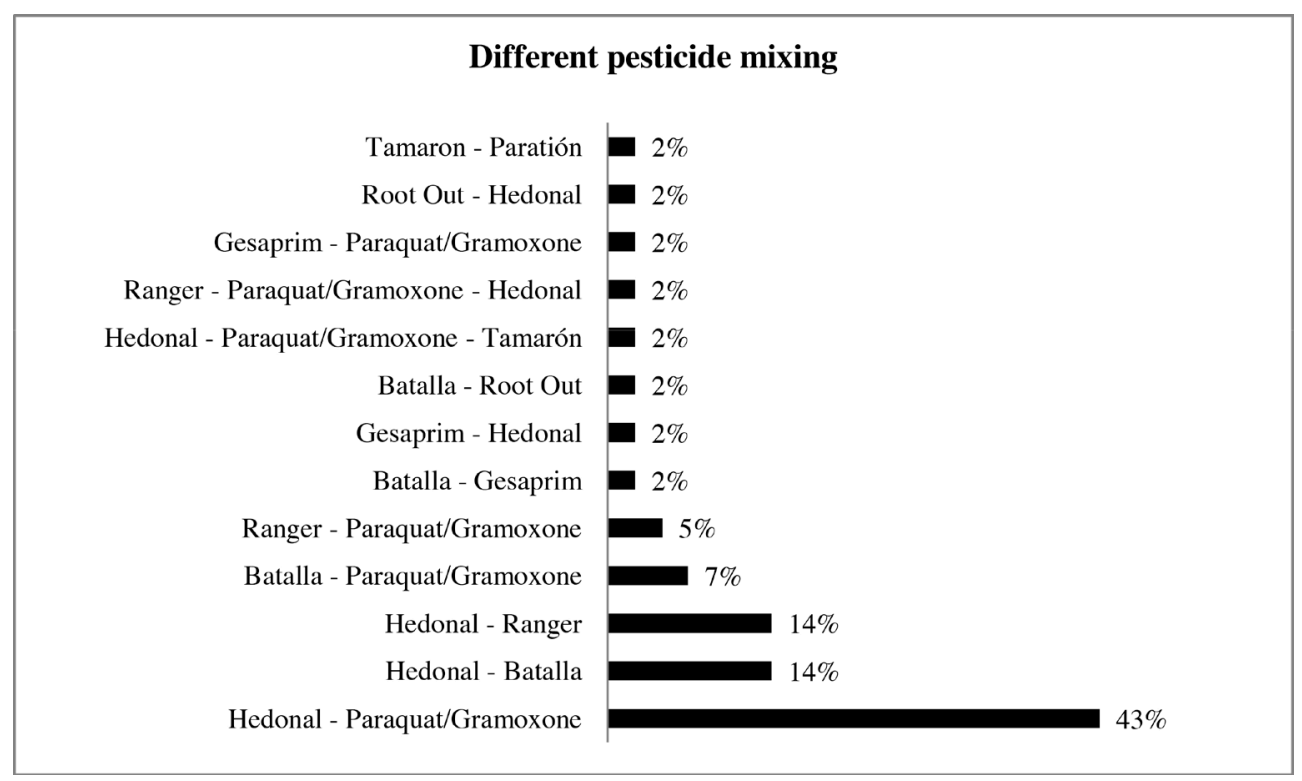

Figure 2. Preparation of pesticides mixing different trademarks. 
Table 1. Identified pesticides.

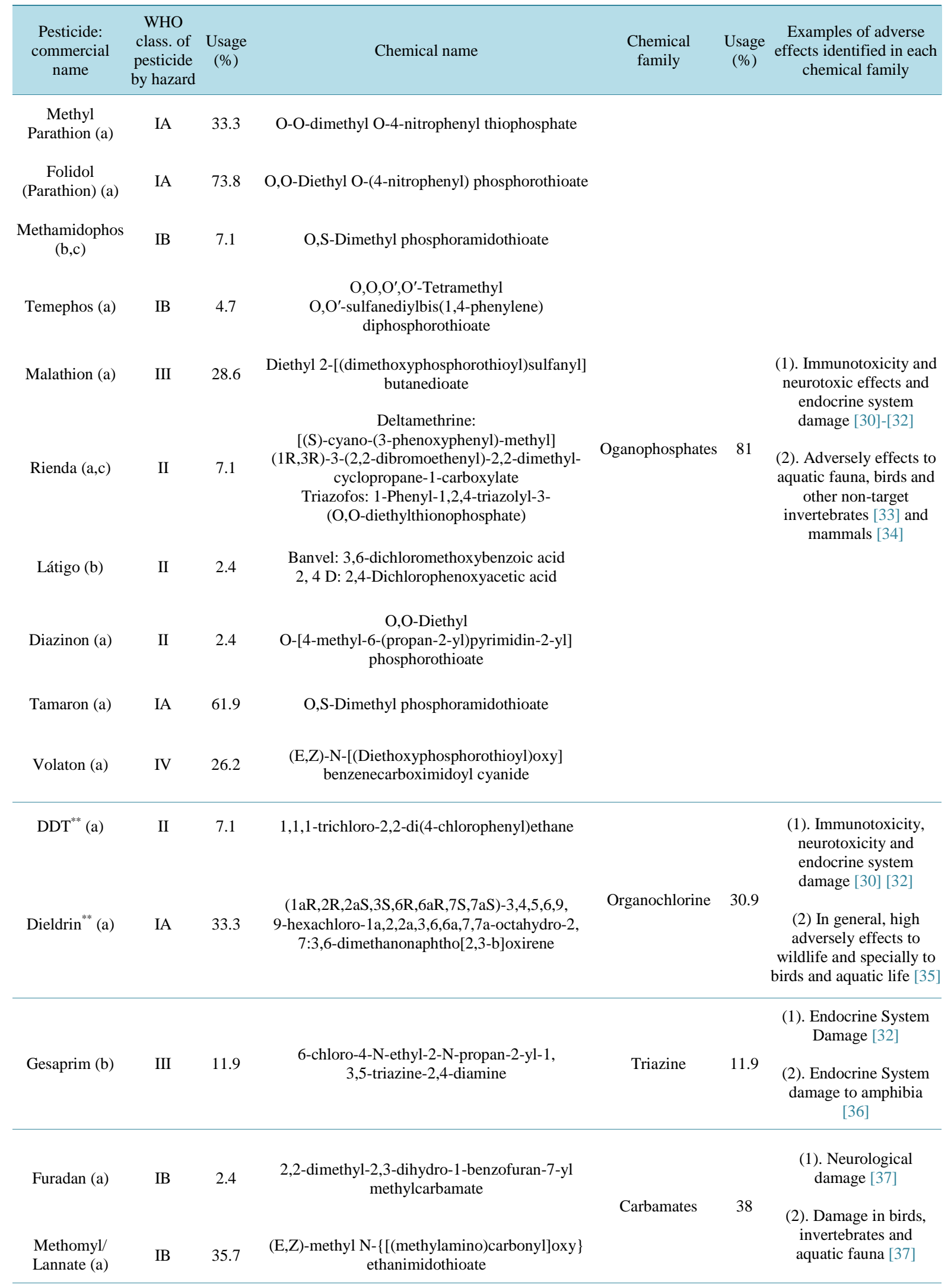




\section{Continued}

\begin{tabular}{|c|c|c|c|c|c|c|}
\hline Karate (a) & II & 57.1 & $\begin{array}{l}\text { Cyhalothrin: [cyano-[3-(phenoxy)phenyl]methyl] } \\
\text { 3-[(Z)-2-chloro-3,3,3-trifluoroprop-1-enyl]-2, } \\
\text { 2-dimethylcyclopropane-1-carboxylate }\end{array}$ & & & \\
\hline Monarca (a) & II & 4.7 & $\begin{array}{c}\text { Cyfluthrin: } \\
\text { [(R)-cyano-[4-fluoro-3-(phenoxy)phenyl]methyl] } \\
\text { (1R,3R)-3-(2,2-dichloroethenyl)-2, } \\
\text { 2-dimethylcyclopropane-1-carboxylate } \\
\text { Thiacloprid: } \\
\text { \{(2Z)-3-[(6-Chloropyridin-3-yl)methyl]-1, } \\
\text { 3-thiazolidin-2-ylidene } \text { cyanamide }\end{array}$ & Pyrethroid & 61.9 & $\begin{array}{l}\text { (1) Endocrine System } \\
\text { Damage [32] } \\
\text { (2) Effects in aquatic } \\
\text { fauna [38] }\end{array}$ \\
\hline $\begin{array}{l}\text { Cypermethrin } \\
\text { (a) }\end{array}$ & II & 2.4 & $\begin{array}{l}\text { [Cyano-(3-phenoxyphenyl)methyl]3- } \\
\text { (2,2-dichloroethenyl)-2, } \\
\text { 2-dimethylcyclopropane-1-carboxylate }\end{array}$ & & & \\
\hline
\end{tabular}

(1) Adversely effects to the lungs, nerve system,

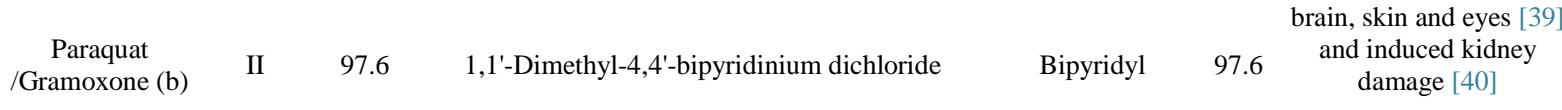

(2)Adversely effects to birds [41]

\begin{tabular}{|c|c|c|c|c|c|c|}
\hline & & & (2,4-dichlorophenoxy)acetic acid & \multirow{3}{*}{$\begin{array}{l}\text { Phenoxyacetic } \\
\text { Acid Group }\end{array}$} & \multirow{3}{*}{100} & (1) Endocrine cancers, \\
\hline $\begin{array}{l}\text { Hedonal/ } \\
2,4 \mathrm{D} \text { (b) }\end{array}$ & II & & Picloram:Picloramtriisopropanolamine salt & & & $\begin{array}{l}\text { damage in renal function } \\
\text { [42] }\end{array}$ \\
\hline Tordon (b) & III & 2.4 & $\begin{array}{c}\text { 2,4-D: 2,4-Dichlorophenoxyacetic acid, } \\
\text { triisopropanolamine salt }\end{array}$ & & & $\begin{array}{l}\text { (2) Adversely effects to } \\
\text { fish [43] }\end{array}$ \\
\hline
\end{tabular}

(1) Acute toxicity is related to respiratory $\begin{array}{ccc}\text { Imidacloprid (a) } \quad \text { II } \quad 2.4 & \text { N-[1-[(6-Chloro-3-pyridyl)methyl]-4, } & \text { Cloronicotinyl } \\ \text { 5-dihydroimidazol-2-yl]nitramide }\end{array}$ failure and reduced level of consciousness [44]

(2) Adversely effects to non-target invertebrates [45]

(1) Chronic exposition associated to Autism, Parkinson [46] and

$\begin{array}{ccc}\text { Roundup (b) } & \text { U } & 83.3 \\ \text { Root Out (b) } & \text { IV } & 7.1 \\ \text { Batalla (b) } & \text { III } & 73.8\end{array}$

$\mathrm{N}$-(phosphonomethyl)glycine $\mathrm{N}$-(phosphonomethyl)glycine

otential cause of $\mathrm{CKDu}$
$\mathrm{N}$-(phosphonomethyl)glycine
(2) Genotoxicity in amphibian [49] and fish [50]

*Ia: Extremely Hazardous; Ib: Highly Hazardous; II: Moderately Hazardous; III: Slightly hazardous; and U: Unlikely; (a) Insecticide; (b) Herbicide; (c) Acaricid; ${ }^{* *}$ Banned in El Salvador since 2000 (Agriculture and Livestock Ministry of El Salvador, Agreement No. 151 dated June 27, 2000) [29]; (1) Health effects; (2) Environmental Effects.

Farmers do not wear PPE properly for preventing intoxications during preparation of solutions, mixing and application of pesticides (100\%). However they wear clothes and devices as preventive measures for avoiding intoxication but usually this gear is not the recommended by the label or Safe Data Sheet (SDS). As it is shown in Figure 3 farmers wore boots (30\%), some wore trousers and long-sleeved shirt (23\%) and only few wore gloves (10\%), facemask (10\%) and/or goggles (3\%).

For most farmers, workday begins at 5:00 AM ending at 11:00 AM (68\%). However some of them worked during the afternoon (38\%) as well. This workday is dedicated to different agriculture activities (seed preparation, tilling soil, burning weeds and pesticides application). The majority of surveyed patients apply pesticides 1 - 4 times per year (72\%), few apply 5 to 8 times (15\%) and the rest (13\%) apply more than 9 times. Farmers spend an average of 4 hours in pesticide application but this period can be extended some times as long as 12 hours. 


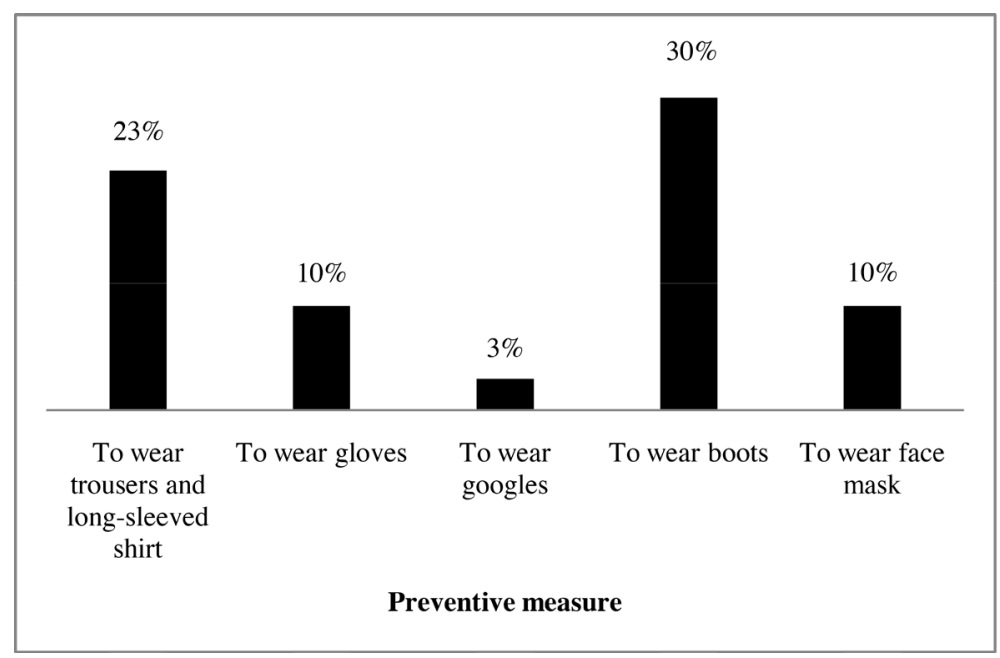

Figure 3. Preventive measures practiced by farmers interviewed.

Figure 4 shows the number of years of exposure to pesticides considering 5 years period in their lives. As shown in Figure 4, farmers are involved in pesticide management during an important period of their lives, 26\% have manipulated pesticides between 16 and 20 years, 19\% have been exposed from 11 to 15 years, others in a period of 6 - 10 years (19\%) as well as in a period from 1 to 5 years (17\%) and only few farmers have handled pesticides more than 25 years (11\%). Finally, some farmers explained that during their working activities, they also have been exposed to aerial pesticide spraying (29\%) from 1 to 8 times a year.

Table 2 classifies the identified pesticides according to their ban in El Salvador, USA and the European Union or as recommended by international organisms or conventions(Rotterdam Convention 2010, PAN 2013, Stockholm Convention 2008, EPA 2013).

\section{Discussion}

Most farmers have been exposed somewhere between 6 to 20 years to Extremely Hazardous pesticides (Grade Ia), Highly Hazardous pesticides (Grade Ib) and Moderately Hazardous pesticides (Grade II). The most hazardous pesticides (Grade Ia and Ib) are classified as organophosphate and as carbamate chemical families. The most used trademarks are the herbicides Hedonal/2,4-D (grade II), Paraquat/Gramoxone (Grade II), Roundup (Grade U), and Batalla (Grade III) and the insecticide Folidol (Grade Ia). All these products are legal in El Salvador. However, Paraquat and Folidolare banned in other parts of the world, such as the European Union [15]. Overall acute poisonings in El Salvador, 22.8\% have been caused by Paraquat [11]. There are not restrictions about the other three pesticides (Hedonal/2,4-D, Roundup, and Batalla), but some studies relate several health problems to them. Endocrine related cancers have been associated to Hedonal/2,4-D [42] and several diseases, as Autism and Parkinson's as well as kidney disease have been related to glyphosate, the active ingredient in Roundup and Batalla [46]. The chemical name and the examples will help to understand possible links among the pesticide compounds and their possible acute and chronic effects. It is easy to find in the literature a lot of examples of the acute effects of pesticide poisoning however the papers related to chronic effects are less numerous, especially about the recent pesticides. DDT and Dieldrin are banned in El Salvador; however, according to patient's responses, they claim to use these substances, but this fact could not be verified through field visits. This could imply poor enforcement of the law or that it is possible to have access to these substances through smuggling or by other illegal ways. From the pesticides list, that Rotterdam Convention suggests to ban [16], El Salvador banned DDT and Dieldrin but has not banned yet other pesticides. The Salvadoran legislation [54] only establishes certain restrictions (for example aerial spraying application is not allowed) for Methyl Parathion and Tamarón/Metamidophos. But nonetheless Folidol/Parathion is still marketed without any restriction [54].

Generally interviewed farmers are exposed to pesticides in all the different stages of agricultural production. The formulation and application phase, which in general are the most hazardous phases [55] are done 1 to 4 times a year and spends around four hours for each application, which may vary depending on the crop and extension of application area. 


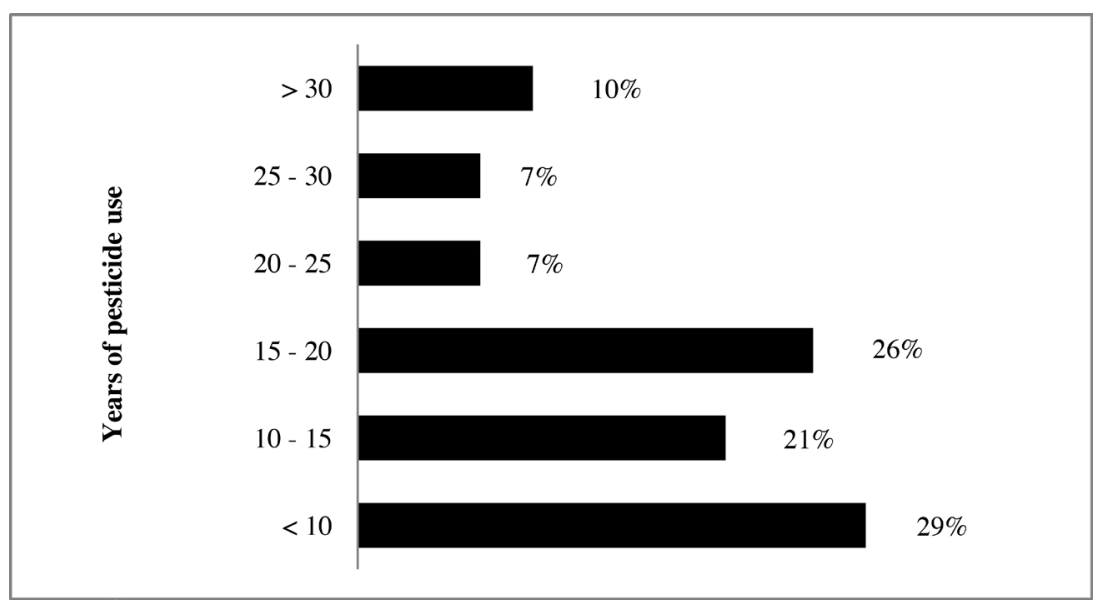

Figure 4. Time exposure of pesticides of sampled population.

Table 2. Pesticides banned or restricted in El Salvador and worldwide.

\begin{tabular}{|c|c|c|c|c|c|c|}
\hline $\begin{array}{l}\text { Pesticides use in Bajo } \\
\text { Lempa region }\end{array}$ & $\begin{array}{l}\text { Pesticidebanned } \\
\text { in El Salvador } \\
\text { [29] }\end{array}$ & $\begin{array}{c}\text { Pesticide } \\
\text { Action } \\
\text { Network [51] }\end{array}$ & $\begin{array}{c}\text { Stockholm } \\
\text { Convention } \\
\text { [52] }\end{array}$ & $\begin{array}{c}\text { Rotterdam Convention } \\
{[16]}\end{array}$ & $\begin{array}{c}\text { Environmental } \\
\text { Protection Agency } \\
\text { [53] }\end{array}$ & $\begin{array}{l}\text { European } \\
\text { Union [15] }\end{array}$ \\
\hline Paraquat/Gramoxone & & $\mathrm{X}$ & & & & $\mathrm{X}$ \\
\hline Methyl Parathion & & $\mathrm{X}$ & & $\mathrm{X}$ & $\mathrm{X}$ & $\mathrm{X}$ \\
\hline Folidol/Parathion & & $\mathrm{X}$ & & $\mathrm{X}$ & $\mathrm{X}$ & $\mathrm{X}$ \\
\hline Dieldrin & $\mathrm{X}$ & $\mathrm{X}$ & $\mathrm{X}$ & $\mathrm{X}$ & $\mathrm{X}$ & $\mathrm{X}$ \\
\hline DDT & $\mathrm{X}$ & $\mathrm{X}$ & $\mathrm{X}$ & $\mathrm{X}$ & $\mathrm{X}$ & $\mathrm{X}$ \\
\hline $\begin{array}{c}\text { Tamarón/ } \\
\text { Methamidophos* }\end{array}$ & & & & $\begin{array}{c}\mathrm{X} \\
600 \mathrm{~g} / \mathrm{l} \text { (SL) formulation } \\
\text { and higher }\end{array}$ & $\begin{array}{c}\mathrm{X} \\
600 \mathrm{~g} / \mathrm{l} \text { (SL) formulation } \\
\text { and higher }\end{array}$ & $\mathrm{X}$ \\
\hline Malathion & & & & & & $\mathrm{X}^{* *}$ \\
\hline $\begin{array}{l}\text { Rienda (Containing active } \\
\text { ingredient: Triazophos) }\end{array}$ & & & & & & $\mathrm{X}$ \\
\hline $\begin{array}{l}\text { Furadan (Containing active } \\
\text { ingredient: Carbofurán) }\end{array}$ & & & & & $\mathrm{X}$ & $\mathrm{X}$ \\
\hline Diazinon & & & & & & $\mathrm{X}$ \\
\hline $\begin{array}{l}\text { Karate (Containing active } \\
\text { ingredient: Cyhalothrin) }\end{array}$ & & & & & & $\mathrm{X}$ \\
\hline
\end{tabular}

*Banned by Rotterdam Convention and EPA if concentrations are $600 \mathrm{~g} / \mathrm{l}$ (SL) formulation and higher; ${ }^{* *}$ Authorized in Spain.

According to the obtained results, the majority of patients carry out bad practices in all stages of pesticides handling. The educational level is very important during the selection and purchase of pesticides. A research carried out in Brazilian Amazon [28] identifies the problem for reading and understanding labels as a common factor in developing countries and relates it to the low cultural level of the users and the excessive difficulty of understanding the technical language of the labels. The interviewed population is not an exception, around half population is semi-illiterate with poor reading skills and $19 \%$ are illiteracy. There are a significant percentage of cases where the pesticide dealers do not provide SDS to farmers. Generally, these sheets provide insight into the use recommendations across standardized diagrams in a user-friendly manner. In some countries there is a legal requirement that implies that each product should to be supplied with a SDS [56] but Salvadoran law does not compel the proportion of this material at the time of product sale.

The mobilization of pesticides in crowded buses or pick-ups extends the exposure of these products to other people and animals. Buses and pick-ups in most developing countries are the main means of transportation in rural areas. This type of transport is used not only to carry people but also to supply goods to the communities [57]. 
Incorrect pesticides storage at home exposes the farmer and his family, as well as livestock and pets. The amounts of these pesticides are usually not very large because farmers usually store at home the products used on the family orchards. However, these represent an important risk because pesticides are accessible to children. This exposure would be much longer if it is considered the leftover solution storage. This storage also poses the environment at risk because of its proximity of domestic wells and latrines in most dwellings. This exposure may be higher because the Bajo Lempa region has shallow water table and because it is very vulnerable to flooding due to increased flow in the Lempa River during the rainy season [58].

Formulation stage is carried out in crop fields, this minimized exposition farmer's family. Interviewed patients mix different types of pesticides without knowing their compatibility, creating compounds that are unknown and with health implications not accurately known yet [59] [60]. Several international institutions recommend mixing pesticides only chemically and physically compatibles [61].

The hand-operated pump with a spray lance used by the surveyed farmers is exposes them more than the application using other methods like mechanical pumps on tractors [62]. The identified disposal practices of pesticide leftover solution and waste are very pollutant and dangerous for the environment. The reapplication of waste solutions, by most farmers, folds the recommended dose and often results in damage to crops, leaving residues in harvested products and/or harmful residues in the soil [5]. The observed final disposal of the empty containers also represents a potential risk for the environment; these unsafe practices (disposal in the field, burning in open fires or burying) are reported as a major problem in a number of studies [63].

Most of patients are not putting any PPE in the application and formulation stages. The use of PPE usually minimizes the absorption of pesticides through the skin, inhalation or ingestion [64] [65]. The lack of PPE use is probably one of the major causes of exposure to pesticides by the farmers. The climate of the area influences the use of PPE because this gear is uncomfortable in tropical temperatures. The use of protection gear also can be related with the education level [66]. In general, these results are consistent with studies carried out in other countries [67], especially in developing countries [7].

The results obtained in this study could be representative patterns of agricultural pesticide management by similar population in the other rural communities in Bajo Lempa, and, in general, for other areas of El Salvador. According to Encuesta de Hogares de Propósitos Multiples 2012 (Survey of Homes with Multiple Purposes 2012) [69]. Salvadoran rural areas present a $43.3 \%$ of inhabitants under the poverty threshold and $19.9 \%$ are illiterate. This implies a situation of high social vulnerability similar to the studied communities.

The effects of the misuse of pesticides may be related to poisonings identified in rural areas and to environmental pollution. According to the Ministry of Health of El Salvador, $75.5 \%$ of the acute poisonings have occurred in rural areas between 2000 and 2012 [11]. Poisonings related to the misuse of pesticides carried out by farmers has been identified in farmers' families, including children [70]. In Bajo Lempa region the impact of the pesticides in the environment has been detected in Jiquilisco Bay, in the Ramsar site close to the studied communities [71] and in the Estero de Jaltepeque [72]. A polluted environment enlarges the exposition of pesticides to farming population. Some pesticides are persistent in the environment and are bioacumulable, and some pesticides, as DDT, create toxics products resulting from their breakdown, too. The ingestion of pesticides through digestive system by polluted drink water and food (fish, meat, vegetables, milk) or through respiratory system from aerosols and dust produces acute and chronic non-occupational poisonings.

The important exposure of the Bajo Lempa farmers to highly toxic pesticides could also be related to possible risk factors for chronic diseases as the CKDu that present all interviewees but, at the moment, the causes of this type of Chronic Kidney Disease have not yet been determined. Published research about this illness in El Salvador [18]-[20] [73] only determine the risk factors related to exposure to pesticides compounded by inadequate working conditions (dehydration, heat stress) because these are only cross-sectional analytical epidemiological studies. Today, there are not yet published cohort studies to evaluate the time of induction of this disease taking into account these risk factors. However, in El Salvador, this type of Chronic Kidney Disease has been described in reports of the National Hospitals since the 90's [74].

The bad practices in all stages of handling pesticides dramatically increase occupational, non-occupational and environmental exposure to pesticides. These bad practices are related with lack of information and lack of technical training of farmers on the proper use of these substances. This situation is consistent with other studies carried out in developing countries [62]-[68].

In El Salvador, it is necessary an effort to apply the law to control the use of banned pesticides, as it has been done in other countries [75]. Also it is important to recognize the extent of the problem and issue a law to in- 
corporate a prohibition to import and use several pesticides that are banned internationally and enforce the application of the law. Initiatives to raise the awareness of farmers of the potential hazards of pesticide use and the proper management of these products could be similar to those proposed by the guidelines developed by the United States Environmental Protection Agency [76]. In the EPA guidelines, each state in the USA carries out a training and certification program that limits the use of restricted pesticides to individuals successfully completing a certification course. The government and the pesticide producers also have to promote initiatives to prevent inappropriate final disposal of leftover pesticide solutions, waste and empty containers.

The results show in this study just represent a part of the population exposed to hazardous of pesticides. The exposure of pesticide in El Salvador is a complex problem which aftermath are evidenced in the high number of acute poisoning reported by Ministry of Health of El Salvador [11] and with a possible link as a causal factor of CKDu [17] [77]. Specific experiments with animals and the combination of pesticides that people have been using in Bajo Lempa should be done. Those experiments could provide information about the mechanisms of occurrence of the disease and which pesticides are more toxic to the kidney. Finally, it is also necessary to carry out a study that involves the population in general and also represents the non-occupational risk derivate from the intensive use of pesticides in the region to address in a complete way this health problem.

\section{Conclusions}

The patients in this study have been exposed for more than 10 years to highly hazardous pesticides. Some of these pesticides are banned and some are legal but prohibited by other countries or international conventions due its high toxicity to human health and the environment. Farmers with CKDu have had high exposure to toxic pesticides due to the misuse in almost all stages of pesticide management. This exposure has to be added to the intrinsic exposure that implies the proper use of pesticides.

The mismanagement of pesticides by patients, especially in the storage stage, also implies a remarkable nonoccupational risk, especially among children. The inappropriate pesticide waste disposal is an important environmental pollution source. The high exposition produced by the large use of hazardous pesticides and their misuse in all the stages of their management by farmers with CKDu in Bajo Lempa region evidence the importance of implementing educational programs focused to prevent the occupational toxics risk in agricultural communities. Also these results show that in El Salvador there is incomplete legislation and a poor law enforcement to prevent the misuse of pesticides.

The information obtained in this study has been useful for Ministry of Health of El Salvador for carry out educational programs focused to prevent the occupational risk on agricultural populations, as well as tools that are useful in decision making for regulating and/or prohibiting the use of highly hazardous pesticides in El Salvador.

\section{Acknowledgements}

This research work has been partially supported by Spanish Agency for International Development Cooperation (AECID, the Spanish acronym) funded by project Development and strengthening of National Institute of Health of the Ministry of Health of El Salvador. We want to thank the local farmers for their collaboration. We are deeply thankful to The United Communities of the Bajo Lempa (ACUDESBAL, the Spanish acronym) for hosting and guiding us in the communities of Bajo Lempa. We also have to thank to technical staff of National Institute of Health of Ministry of Health of El Salvador for their continuous help. We acknowledge the helpful language suggestions from Ms. B. Bustamante. Finally, we would like to thank specially to Dra. Maria Isabel Rodríguez, former Salvadoran Health Minister, for her strategic support.

\section{References}

[1] Forget, G. (1993) Balancing the Need for Pesticides with the Risk to Human Health: Impact of Pesticide Use on Health in Developing Countries. Proceedings of a Symposium Held in Ottawa, 17-20 September 1990, 2-16. http://idl-bnc.idrc.ca/dspace/bitstream/10625/18585/1/93970_p2-16.pdf

[2] WHO (2009) The WHO Recommended Classification of Pesticides by Hazard and Guidelines to Classification. http://www.inchem.org/documents/pds/pdsother/class_2009.pdf

[3] Farcas, A., Matei A.V., Florian, C., Badea, M. and Coman, G. (2013) Health Effects Associated with Acute and Chronic Exposure to Pesticides. In: Simeonov, L.I., MAcaev, F.Z. and Simeonova, B.G., Eds., Environmental Security 
Assessment and Management of Obsolete Pesticides in Southeast Europe, Springer, Dordrecht, 103-110.

[4] Pimentel, D., Acquay, H., Biltonen, M., Rice, P., Silva, M., Nelson, J., et al. (1992) Environmental and Economic Costs of Pesticide Use, BioScience, 42, 750-760. http://www.jstor.org/stable/1311994

[5] Damalas, C.A., Telidis, G.K. and Thanos, S.D. (2008) Assessing Farmers' Practices on Disposal of Pesticide Waste after Use. Science of the Total Environment, 390, 341-345. http://dx.doi.org/10.1016/j.scitotenv.2007.10.028

[6] Keifer, M.C. (2000) Effectiveness of Interventions in Reducing Pesticide Overexposure and Poisonings. American Journal of Preventive Medicine, 18, 80-89. http://dx.doi.org/10.1016/S0749-3797(00)00144-6

[7] Lozier, M.J., López, J.F., del Rosario, A., Pintor, E., Fuortes, L., Cook, T.M., et al. (2013) Personal Air Sampling and Risks of Inhalation Exposure during Atrazine Application in Honduras. International Archives of Occupational and Environmental Health, 86, 479-488. http://dx.doi.org/10.1007/s00420-012-0776-2

[8] Mekonnen, Y. and Agonafir, T. (2002) Pesticide Sprayers’ Knowledge, Attitude and Practice of Pesticide Use on Agricultural Farms of Ethiopia. OccupMed, 6, 311-315. http://dx.doi.org/10.1093/occmed/52.6.311

[9] Jenkins, J.J. (2003) Aspectos sanitarios de los plaguicidas en El Salvador en el contexto Centroamericano. Plaguicidas y Salud en El Salvador: Aproximación a la Problemática. 1st Edition, Organización Panamericana de la Salud, San Salvador.

[10] Murray, D., Wesseling, C., Keifer, M., Corriols, M. and Henao, S. (2002) Surveillance of Pesticide-Related Illness in the Developing World: Putting the Data to Work. International Journal of Occupational and Environmental Health, 8, 243-248.

[11] Ministerio de Salud (SV) (2013) Reporte de intoxicaciones por plaguicidas 2007-2012. http://simmow.salud.gob.sv

[12] VanDervort, D.R., Lopez, D.L., Orantes, C.M. and Rodríguez, D.S. (2014) Spatial Distribution of Unspecified Chronic Kidney Disease in El Salvador by Crop Area Cultivated and Ambient Temperature. MEDICC Review, 16, 31-38. http://www.medicc.org/mediccreview/pdf.php?lang=\&id=352.

[13] Ministerio de Agricultura y Ganadería de El Salvador. Manual de Insumos Agrícolas 2012 (2012) Dirección General de Economía Agropecuaria.

http://www.mag.gob.sv/index.php?option=com phocadownload\&view=category\&id=21\&Itemid=232

[14] Barrera, A.M. (2009) Estudio de Concentración de Mercado de Agroquímicos en El Salvador. Ministerio de Agricultura y Ganadería de El Salvador, El Salvador.

[15] EuropeanCommission (2013) EU Pesticides Database. http://ec.europa.eu/sanco pesticides/public/index.cfm?event=activesubstance.selection

[16] Rotterdam Convention (2010) http://www.pic.int/

[17] NationalInstitute of Health (SV) (2013) Declaración de San Salvador Abordaje integral de la enfermedad renal túbulointersticial crónica de Centroamérica (CKDu) que afecta predominantemente a las comunidades agrícolas. Ministry of Public Health (SV), San Salvador. http://www.salud.gob.sv/

[18] Orantes, C.M., Herrera, R., Almaguer, M., Brizuela, E., Núñez, L., Alvarado, N., Fuentes, J., Bayarre, H., et al. (2014) Epidemiology of Chronic Kidney Disease in Adults of Salvadoran Agricultural Communities. MEDICC Review, 16, 23-30. http://www.medicc.org/mediccreview/pdf.php?lang=\&id=351

[19] Peraza, S., Wesseling, C., Aragon, A., Leiva, R., García-Trabanino, R.A., Torres, C., Jakobsson, K., Elinder, C.G. and Hogstedt, C. (2012) Decreased Kidney Function among Agricultural Workers in El Salvador. American Journal of Kidney Diseases, 59, 531-540. http://www.ncbi.nlm.nih.gov/pubmed/22300650 http://dx.doi.org/10.1053/j.ajkd.2011.11.039

[20] Orantes, C.M., Herrera, R., Almaguer, M., Brizuela, E.E., Hernández, C.E., Bayarre, H., et al. (2011) Chronic Kidney Disease and Associated Risk Factors in the Bajo Lempa Region of El Salvador: Nefrolempa Study, 2009. MEDICC Review, 13, 14-22. http://www.medicc.org/mediccreview/pdf.php?lang=en\&id=221

[21] Orantes, C.M. (2010) Enfermedad renal crónica y factores de riesgo en el Bajo Lempa, El Salvador: Estudio Nefrolempa. Ministryof Health (SV), San Salvador.

[22] Medina, R., García, M., de Larios, S., Gómez, I., Cuellar, N. and Rosa, H. (2002) Dimensiones Ambientales de la Vulnerabilidad en El Salvador: El Caso del Bajo Lempa. PRISMA, San Salvador.

http://www.prisma.org.sv/uploads/media/dimensiones_ambientales_de_la_vulnerabilidad_en_ESV_caso_bajolempa.pd $\underline{\mathrm{f}}$

[23] Sudmeier-Rieux, K., Masundire, H., Rizvi, A. and Rietbergen, S. (2006) Ecosystems, Livelihoods and Disasters: An Integrated Approach to Disaster Risk Management. IUCN, Gland.

http://proactnetwork.org/proactwebsite/media/download/resources/Ecosystem-based-DRR/IUCN_ecosystems_liveliho ods_disasters_2006.pdf

[24] Schipper, L.F. (2004) Exploring Adaptation to Climate Change: A Development Perspective. Ph.D. Thesis, University 
of East Anglia, Norwich.

[25] Schipper, L.F. (2006) Climate Risk, Perceptions and Development in El Salvador. Tyndall Centre Working Paper 93. International Water Management Institute Colombo, Sri Lanka.

http://www.tyndall.ac.uk/sites/default/files/wp93.pdf.

[26] Komar, O. (2002) Priority Conservation Areas for Birds in El Salvador. Animal Conservation, 5, 173-183. http://dx.doi.org/10.1017/S1367943002002238

[27] EPA (2006) Protect Yourself from Pesticides: Guide for Pesticides Handlers. United States Environmental Protection Agency. EPA, Washington. http://www.epa.gov/region1/eco/pest/pdfs/PesticideHandlersSafetyTrainingManualEnglish.pdf

[28] Waichman, A.V., Eve, E. and Nina, N.C. (2007) Do Farmers Understand the Information Displayed on Pesticide Product Labels? A Key Question to Reduce Pesticides Exposure and Risk of Poisoning in the Brazilian Amazon. Crop Protection, 26, 576-583. http://dx.doi.org/10.1016/j.cropro.2006.05.011

[29] Ministerio de Agricultura y Ganadería de El Salvador (2000) Listado de sustancias prohibidas en El Salvador. http://www.marn.sv/component/phocadownload/category/29-formularios-solicitudes-residuos-desechos-peligrosos.htm l?download=177:listado-de-sustancias-prohibidas-en-el-salvador

[30] Galloway, T. and Handy, R. (2003) Immunotoxicity of Organophosphorous Pesticides. Ecotoxicology, 12, $345-363$. http://dx.doi.org/10.1023/A:1022579416322

[31] Salomon, G., Onguseitan, O.A. and Kirsch, J. (2000) Pesticides and Human Health, a Resource for Health Care Professionals. Physicians for Social Responsability and Californians for Pesticide Reform. Californians for Pesticide Reform, Oakland. http://pesticidereform.org/section.php?id=13

[32] McKinlay, R., Plant, J.A., Bell, J.N.B. and Voulvoulis, N. (2008) Endocrine Disrupting Pesticides: Implications for Risk Assessment. Environmetal International, 34, 168-183. http://dx.doi.org/10.1016/j.envint.2007.07.013

[33] Newhart, K.L. (2006) Environmental Fate of Malathion. California Department of Pesticide Regulation. http://www.cdpr.ca.gov/docs/emon/pubs/fatememo/efate_malathion.pdf

[34] Pope, C.N. and Chakraborti, T.K. (1992) Dose-Related Inhibition of Brain and Plasma Cholinesterase in Neonatal and Adult Rats Following Sublethal Organophosphate Exposures. Toxicology, 73, 35-43. http://dx.doi.org/10.1016/0300-483X(92)90168-E

[35] US Fish \& Wildlife Service (2014) DDT and Other Organochlorine Pesticides. US Fish and Wildlife Service Division of Environmental Quality. http://www.fws.gov/contaminants/info/ddt.html.

[36] Hayes, T., Haston, K., Tusi, M., Hoang, A., Haeffele, C. and Vonk, A. (2003) Atrazine-Induced Hermaphroditism at $0.1 \mathrm{ppb}$ in American Leopard Frogs (Rana pipiens): Laboratory and Field Evidence. Environmental Health Perspectives, 111, 568-575. http://www.ncbi.nlm.nih.gov/pmc/articles/PMC1241446/

[37] US. EPA (2012) Carbofuran I.R.E.D. FACTS. US Environmental Protection Agency (EPA). http://www.epa.gov/oppsrrd1/REDs/factsheets/carbofuran ired fs.htm

[38] Agency for Toxic Substances and Disease Registry (2014) Public Health Statement for Pyrethrins and Pyrethroids. http://www.atsdr.cdc.gov/phs/phs.asp?id=785\&tid=153

[39] Guo, Y.L., Wang, B.J., Lee, C.C. and Wang, J.D. (1996) Prevalence of Dermatoses and Skin Sensitisation Associated with Use of Pesticides in Fruit Farmers of Southern Taiwan. Occupational and Environmental Medicine, 53, 427-431. http://dx.doi.org/10.1136/oem.53.6.427

[40] Hong, S.Y., Yang, D.H. and Hwang, K.Y. (2000) Associations between Laboratory Parameters and Outcome of Paraquat Poisoning. Toxicology Letters, 118, 53-59. http://dx.doi.org/10.1016/S0378-4274(00)00264-2

[41] US EPA (1997) Registration Eligibility Decision (RED): Paraquat Dichloride. US Environmental Protection Agency (EPA). http://www.epa.gov/oppsrrd1/REDs/0262red.pdf

[42] Goldsmith, D.F. (2000) Linking Environmental Cancer with Occupational Epidemiology Research: The Role of the International Agency for Research on Cancer (IARC). Journal of Environmental Pathology, Toxicology and Oncology, 19, 171-175. http://www.ncbi.nlm.nih.gov/pubmed/10905524

[43] Walters, J. (1999) Environmental Fate of 2,4-Dichlorophenoxyacetic Acid. California Department of Pesticide Regulation. Environmental Monitoring and Pest Management Department of Pesticide Regulation Sacramento, CA 95814-3510. http://www.cdpr.ca.gov/docs/emon/pubs/fatememo/24-d.pdf

[44] Kumar, A., Verma, A. and Kumar, A. (2013) Accidental Human Poisoning with a Neonicotinoid Insecticide, Imidacloprid: A Rare Report from Rural India. Egyptian Journal of Forensic Sciences, 3, 123-126. http://dx.doi.org/10.1016/j.ejfs.2013.05.002

[45] Papachirstos, D.P. and Milonas, P.G. (2008) Adverse Effects of Soil Applied Insecticides on the Predatory Coccinellid Hippodamia undecimnotata (Coleoptera: Coccinellidae). Biological Control, 47, 77-81. 
http://dx.doi.org/10.1016/j.biocontrol.2008.06.009

[46] Samsel, A. and Seneff, S. (2013) Glyphosate’s Suppression of Cytochrome P450 Enzymes and Amino Acid Biosynthesis by Gut Microbiome: Pathways to Modern Diseases. Entropy, 15, 1416-1463. http://dx.doi.org/10.3390/e15041416

[47] Jayasumana, C., Gunatilake, S. and Senanayake, P. (2014) Glyphosate, Hard Water and Nephrotoxic Metals: Are They the Culprits behind the Epidemic of Chronic Kidney Disease of Unknown Etiology in Sri Lanka? International Journal of Environmental Research and Public Health, 11, 2125-2147. http://dx.doi.org/10.3390/ijerph110202125

[48] Paz-y-Miño, C., Sánchez, M.E., Arevalo, M., Muñoz, M.J., Witte, T., De-la-Carrera, G.O. and Leone, P.E. (2007) Evaluation of DNA Damage in an Ecuadorian Population Exposed to Glyphosate. Genetics and Molecular Biology, 30, 456-460. http://dx.doi.org/10.1590/S1415-47572007000300026

[49] Meza-Joya, F.L., Ramírez-Pinilla, M.P. and Fuentes-Lorenzo, J.L. (2013) Toxic, Cytotoxic, and Genotoxic Effects of a

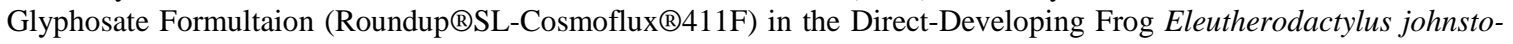
nei. Environmental and Molecular Mutagenesis, 54, 362-373. http://dx.doi.org/10.1002/em.21775

[50] de CastilhosGhisi, N. and Cestari, M.M. (2013) Genotoxic Effects of the Herbicide Roundup ${ }^{\circledR}$ in the Fish Corydoras paleatus (Jenyns 1842) after Short-Term, Environmentally Low Concentration Exposure. Environmental Monitoring and Assessment, 185, 3201-3207. http://dx.doi.org/10.1007/s10661-012-2783-X

[51] Pesticide Action Network (2011) List of Prohibited Pesticides. http://sanstandards.org/userfiles/file/SAN\%20Prohibited\%20Pesticide\%20List\%20November\%202011.pdf

[52] Stockholm Convention (2008) Listing of POPs in the Stockholm Convention. http://chm.pops.int/TheConvention/ThePOPs/ListingofPOPs/tabid/2509/Default.aspx

[53] Environmental Protection Agency (2013) List: Banned or Severely Restricted Pesticides (US Environmental Protection Agency). http://www.epa.gov/pesticides/regulating/restricted.htm

[54] Ministerio de Agricultura y Ganadería (SV) (2004) Acuerdo N 18. Diario oficial Republica de El Salvador en la América Central, 362, 18-02-2004 http://www.diariooficial.gob.sv/diarios/do-2004/02-febrero/

[55] Jeyaratnam, J., Lun, K.C. and Phoon, W.O. (1987) Survey of Acute Pesticide Poisoning among Agricultural Workers in four Asian Countries. Bulletin of the World Health Organization, 65, 521-527.

[56] Occupational Safety Health Administration (2013) Hazard Communication Standard: Safety Data Sheets. https://www.osha.gov/Publications/OSHA3514.html

[57] Ellis, S.D. (1997) Key Issues in Rural Transport in Developing Countries. TRL Report 260. Transport Research Foundation Group of Companies. http://r4d.dfid.gov.uk/pdf/outputs/r5591trl260.pdf

[58] Aguilar, M.Y. (2007) Vulnerabilidad y adaptación al cambio climático de los pobladores rurales de la planicie costera central de El Salvador.

http://www.marn.gob.sv/index.php?option=com content\&view=article\&id=193\&Itemid=252

[59] Schilmann, A., Lacasaña, M., Blanco-Muñoz, J., Aguilar-Garduño, C., Salinas-Rodríguez, A., Flores-Aldana, M. and Cebrián, M.E. (2010) Identifying Pesticide Use Patterns among Flower Growers to Assess Occupational Exposure to Mixtures. Occupational \& Environmental Medicine, 67, 323-329. http://dx.doi.org/10.1136/oem.2009.047175

[60] Carpenter, D.O., Arcaro, K. and Spink, D.C. (2002) Understanding the Human Health Effects of Chemical Mixtures. Environmental Health Perspectives, 110, 25-42. http://dx.doi.org/10.1289/ehp.02110s125

[61] FAO (2001) Guidelines on Good Practice for Ground Application of Pesticides. http://www.fao.org/fileadmin/templates/agphome/documents/Pests_Pesticides/Code/Old_guidelines/Ground_applicatio $\underline{\text { n.pdf }}$

[62] Zyoud, S.H., Sawalha, A.F., Sweileh, W.M., Awang, R., Al-Khalil, S.I., Al-Jabi, S.W. and Bsharat, N.M. (2010) Knowledge and Practices of Pesticide Use among Farm Workers in the West Bank, Palestine: Safety Implications. Environmental Health and Preventive Medicine, 15, 252-261. http://dx.doi.org/10.1007/s12199-010-0136-3

[63] Hashmi, I. and Khan, A.D. (2011) Adverse Health Effects of Pesticides Exposure in Agricultural and Industrial Workers of Developing Country. In: Stoytcheva, M., Ed., Pesticides-The Impacts of Pesticides Exposure, InTech. http://dx.doi.org/10.5772/13835

[64] Archibald, B.A., Solomon, K.R. and Stephenson, G.R. (1995) Estimation of Pesticide Exposure to Greenhouse Applicators Using Video Imaging and Other Assessment Techniques. American Industrial Hygiene Association Journal, 56, 226-235. http://dx.doi.org/10.1080/15428119591017051

[65] Hwang, S.A., Gomez, M.I., Stark, A.D., St John, T.L., Pantea, C.I., Hallman, E.M., May, J.J. and Scofield, S.M. (2000) Safety Awareness among New York Farmers. American Journal of Industrial Medicine, 38, 71-81. http://dx.doi.org/10.1002/1097-0274(200007)38:1<71::AID-AJIM8>3.0.CO;2-X 
[66] Perry, M.J., Marbella, A. and Layde, P.M. (2002) Compliace with Required Pesticide-Specific Protective Equipment Use. American Journal of Industrial Medicine, 41, 70-73. http://dx.doi.org/10.1002/ajim.10026

[67] Mekonnen, Y. and Agonafir, T. (2002) Pesticide Sprayers' Knowledge, Attitude and Practice of Pesticide Use on Agricultural Farms of Ethiopia. Occupational Medicine, 52, 311-315. http://dx.doi.org/10.1093/occmed/52.6.311

[68] Koh, D. and Jeyaratnam, J. (1996) Pesticides Hazards in Developing Countries. Science of the Total Environment, 188, S78-S85. http://dx.doi.org/10.1016/0048-9697(96)05279-5

[69] Ministerio de Economía de El Salvador (2012) Encuesta de Hogares de propósitos múltiples 2012. Survey of Homes with Multiple Purposes 2012. http://www.digestyc.gob.sv/EHPM2012/digestyc/resultado.pdf

[70] Azaroff, L.S. and Neas, L.M. (1999) Acute Health Effects Associated with Nonoccupational Pesticide Exposure in Rural El Salvador. Environmental Research Section A, 80, 158-164. http://dx.doi.org/10.1006/enrs.1998.3878

[71] Nomen, R., Sempere, J., Chávez, F., de López, N.A. and Rovira, M.D. (2012) Measurement of Pollution Levels of Organochlorine and Organophosphorus Pesticides in Water, Soil, Sediment, and Shrimp to Identify Possible Impacts on Shrimp Production at Jiquilisco Bay. Environmental Science and Pollution Research International, 19, 3547-3555. http://www.ncbi.nlm.nih.gov/pubmed/22573096 http://dx.doi.org/10.1007/s11356-012-0916-y

[72] Urrutia, J. and Navas, V.M. (2007) Condiciones de saneamiento de las aguas del estero de Jaltepeque y su relación con la morbilidad. AKADEMOS: Órgano de difusión de la Red Docencia-Investigación. Año 1, 2, 2, 21-34.

[73] Garcia-Trabanino, R., Dominguez, J., Jansa, J.M. and Oliver, A. (2005) Proteinuria e insuficiencia renal crónica en la costa de El Salvador: Detección con métodos de bajocosto y factoresasociados. Nefrología, 25, 31-38.

[74] Almanguer, M., Herrera, R. and Orantes, C.M. (2014) Chronic Kidney Disease of Unknown Etiology in Agricultural Communities. MEDICC Review, 16, 9-15. http://www.medicc.org/mediccreview/pdf.php?lang=\&id=349

[75] Ecobichon, D.J. (2001) Pesticide Use in Developing Countries. Toxicology, 160, 27-33. http://dx.doi.org/10.1016/S0300-483X(00)00452-2

[76] EPA (2011) Code of Federal Regulations Tittle 40 Part 171: Certification of Pesticide Applicators. U.S. Government Printing Office, Washington DC. http://www.gpo.gov/fdsys/granule/CFR-2011-title40-vol24/CFR-2011-title40-vol24-sec171-11/content-detail.html

[77] Pan American Health Organization (2013) 52nd Directing Council of Pan American Health Organization. http://www.paho.org/hq/index.php?option=com_content\&view=category\&layout=blog\&id=1259\&Itemid=1159 
Scientific Research Publishing (SCIRP) is one of the largest Open Access journal publishers. It is currently publishing more than 200 open access, online, peer-reviewed journals covering a wide range of academic disciplines. SCIRP serves the worldwide academic communities and contributes to the progress and application of science with its publication.

Other selected journals from SCIRP are listed as below. Submit your manuscript to us via either submit@scirp.org or Online Submission Portal.
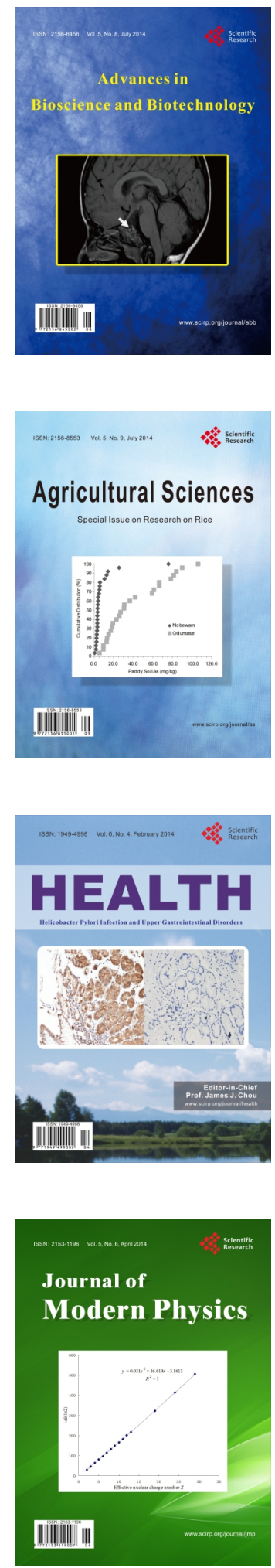
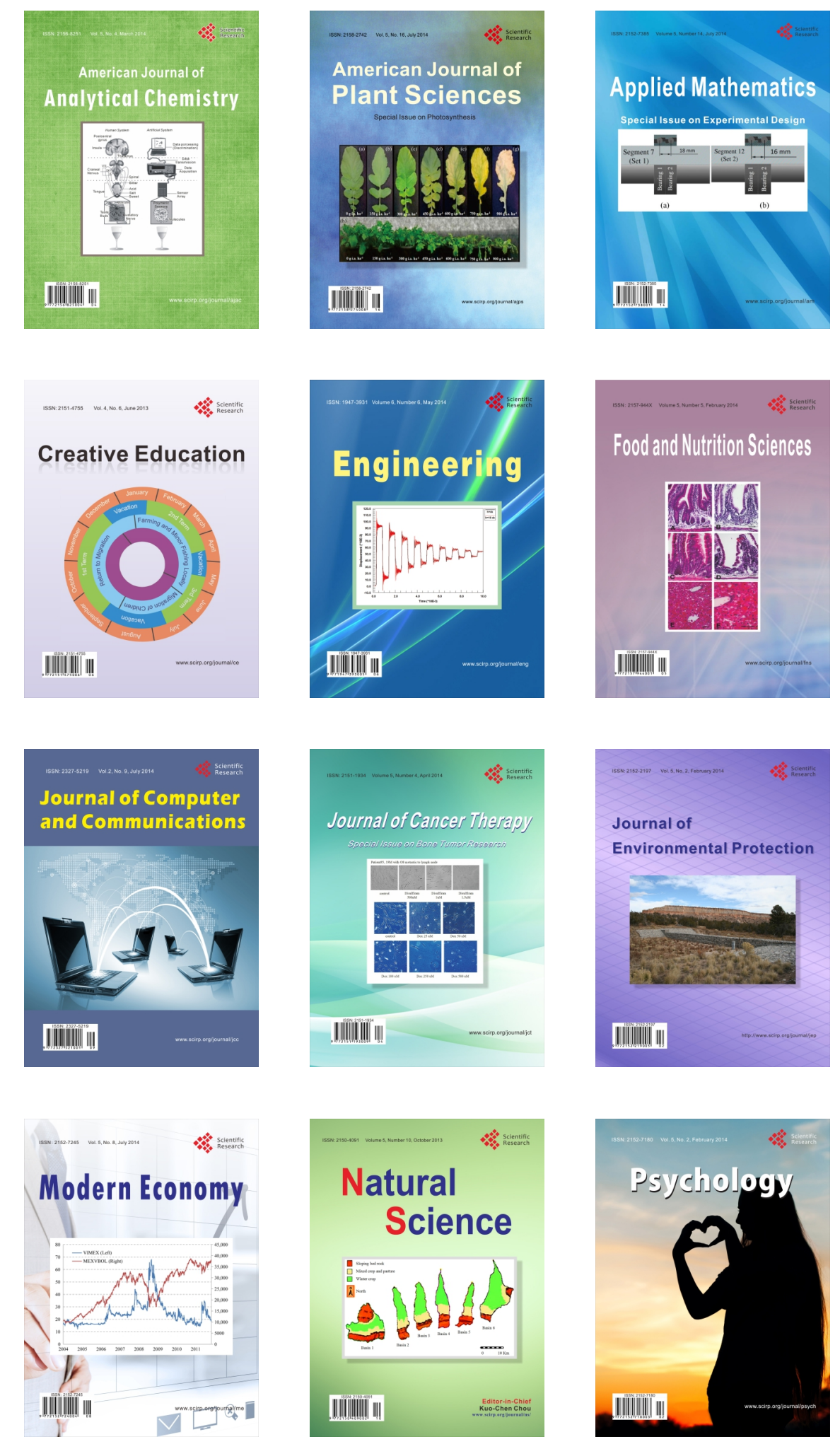